JAN GRZESZCZAK

\title{
Jego Ekscelencja Ksiądz Arcybiskup Marek Jędraszewski Człowiek - Biskup - Filozof
}

\author{
Ekscelencje, \\ Magnificencjo, Szanowny Panie Rektorze, \\ Szanowni Państwo,
}

Deum et animam scire cupio. Nihilne plus. Nihil omnino („Chcę poznać Boga i duszę. Czy nic więcej? Nic zgoła") ${ }^{1}$ - prosi młody Augustyn w Solilokwiach, powstałych w zaciszu willi w Cassiciacum jako owoc samotnych rozważań o zagadnieniach, które przyszły biskup Hippony najbardziej pragnął zgłębić.

Wydaje się, że ze względu na wielość podejmowanych spraw, dużych i małych, takie samotne rozważania są dla biskupa swego rodzaju luksusem. Jest to jednak luksus konieczny, który chroni go w sprawowanej posłudze przed wieloma niebezpieczeństwami oraz pomaga w osobistym uświęceniu i skutecznym przekazywaniu innym prawd wiary. Stąd też tak modli się św. Augustyn na początku przywołanych wyżej Solilokwiów: Deus per quem nos res minutae non minuunt. Deus per quem melius nostrum deteriori subjectum non est („Dzięki Tobie, Boże, nie umniejszają nas rzeczy małe, a to, co w nas jest lepsze, nie podlega temu, co gorsze")2. Wydaje się więc, że bycie biskupem-filozofem służyć może zarówno człowieczeństwu, jak i biskupstwu, a także i samej filozofii. W swoim liście, przygotowanym również na dzisiejszą okoliczność, obecny tutaj Ksiądz Arcybiskup Metropolita Poznański formułuje z tego związku pomiędzy filozofią i biskupią posługą bardzo konkretny postulat: „Choć jedynie nieliczni zajmują się filozofią profesjonalnie, to filozofią szczególnie zajmować się winni biskupi”.

Po tych uwagach wstępnych proszę mi pozwolić na przejście do zasadniczej części, czyli prezentacji sylwetki naszego Dostojnego Jubilata.

Ksiądz Arcybiskup prof. Marek Jędraszewski jest poznaniakiem, urodził się dnia 24 lipca 1949 roku. Tutaj ukończył Szkołę Podstawową nr 38 na Winogradach, a następnie I Liceum Ogólnokształcące im. Karola Marcinkowskiego, gdzie w 1967 roku uzyskał świadectwo dojrzałości. W latach 1967-1973 odbył studia filozoficzno-teologiczne w Arcybiskupim Seminarium Duchownym. Święcenia kapłańskie przyjął dnia 24 maja 1973 roku z rąk księdza arcybiskupa Antoniego

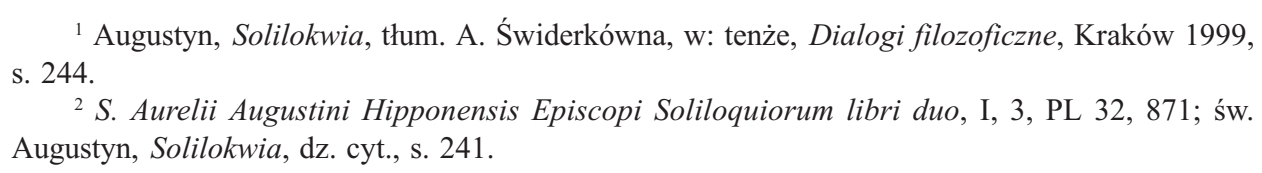

${ }^{1}$ Augustyn, Solilokwia, thum. A. Świderkówna, w: tenże, Dialogi filozoficzne, Kraków 1999,

${ }^{2}$ S. Aurelii Augustini Hipponensis Episcopi Soliloquiorum libri duo, I, 3, PL 32, 871; św. Augustyn, Solilokwia, dz. cyt., s. 241. 
Baraniaka i został skierowany jako wikariusz do parafii pw. św. Marcina w Odolanowie, obecnie na terenie diecezji kaliskiej.

Ta garść faktów z życia Dostojnego Jubilata domaga się jednak krótkiego przywołania tego, co ukształtowało młodość, a zatem również całe Jego dotychczasowe życie. Sam Jubilat wspomina z uznaniem swoich nauczycieli, a zwłaszcza panią Marię Bieniaszewską, nauczycielkę języka polskiego i historii w podstawówce na Winogradach - osobę odważną i zatroskaną o prawdę o naszej historii, i to w czasach, kiedy kłamstwo urosło do rangi oficjalnej wykładni, wsączanej do umysłów dzieci i młodzieży na lekcjach i za pomocą podręczników szkolnych. Wspomina tych, którzy wprowadzili go w tajniki filozofii, zwłaszcza pana prof. Lecha Słowińskiego, który na lekcjach filozofii w poznańskim „Marcinku" zadawał młodzieży lekturę Historii filozofii Władysława Tatarkiewicza, a następnie omawiał z nią zawarte tam kwestie, chroniąc $\mathrm{w}$ ten sposób młode umysły przed „iluzjami marksistowskiej ideologii”. W seminarium poznańskim dokonało się systematyczne już wprowadzenie Jubilata w arkana filozofii. Zajęli się nim dwaj księża profesorowie: Marian Kowalewski oraz niekwestionowany Mistrz, jakim był zmarły w 2000 roku Ludwik Wciórka - wybitny znawca i popularyzator na gruncie polskim myśli francuskiego jezuity, filozofa, geologa i paleontologa Pierre'a Teilharda de Chardina.

A jak wspominają tamten czas osoby, które znały Dostojnego Jubilata? Poznańskie Seminarium Duchowne z przełomu lat sześćdziesiątych i siedemdziesiątych ubiegłego wieku nie różniło się zapewne od pozostałych tego typu kościelnych uczelni $\mathrm{w}$ naszym kraju, o czym świadczą wypowiedzi bliskich kolegów Jubilata z seminaryjnej ławy. Oprócz obowiązków, jakie wyznaczał codzienny i roczny rytm życia kleryckiej wspólnoty, był też czas na rekreację i wakacyjne wyjazdy. Był piłkarzem ,zadziornym, ale nie faulującym” - wspominają Dostojnego Jubilata koledzy; „kochał góry”3. Odwiedzał kolegów, którzy - w myśl panującej wówczas linii ówczesnych władz państwowych - odbywali służbę w kleryckich jednostkach wojskowych.

O rodzącej się wówczas wielkiej pasji filozoficznej Jubilata i ogromnym wpływie ks. prof. Wciórki na umysły młodych adeptów filozofii świadczy zabawny epizod z czasów Jego pobytu na wikariacie w Odolanowie, który pozwolę sobie w tym miejscu przywołać. Jak wspomina jeden z przyjaciół Jubilata,

ks. Tadeusz Neumann, ówczesny proboszcz parafii św. Marcina w Odolanowie, był bardzo o nas zatroskany. Jeździliśmy wieczorami do Poznania, ale nie chcąc martwić proboszcza, mówiliśmy mu, że jedziemy do Gorzyc [nieobeznanym z terenem wyjaśniam, że Gorzyce to miejscowość pod Ostrowem Wlkp., oddalona niecałe $10 \mathrm{~km}$ od Odolanowa]. Aby jednak nie skłamać, wykręcaliśmy po drodze do Gorzyc, tam machaliśmy z samochodu wikariuszowi ks. Świerkowskiemu, a następnie kontynuowaliśmy naszą podróż do Poznania. Jeździliśmy tam na nocne rozmowy z ks. prof.

\footnotetext{
${ }^{3}$ Wspomnienie ks. prałata Tomasza Ilskiego.
} 
Wciórka, przeciagające się grubo po północy; wracaliśmy z nich nad ranem i aby przypadkiem nie zbudzić proboszcza, gasiliśmy silnik i po cichu wpychaliśmy samochód na teren plebanii ${ }^{4}$.

W 1975 roku Jubilat został skierowany na studia specjalistyczne na Wydziale Filozofii Papieskiego Uniwersytetu Gregoriańskiego w Rzymie. O ich przebiegu i charakterze usłyszymy za chwilę od Pana prof. Krzysztofa Stachewicza, wspomnę jednak, że zarówno praca licencjacka Dostojnego Jubilata, poświęcona hermeneutyce Paula Ricoeura, jak i doktorska na temat etyki Emmanuela Levinasa, zostały w szczególny sposób wyróżnione: pierwsza złotym medalem Uniwersytetu Gregoriańskiego, a druga złotym medalem Ojca Świętego Jana Pawła II.

Po powrocie do Polski Dostojny Jubilat pracował jako prefekt w Arcybiskupim Seminarium Duchownym w Poznaniu, a także jako adiunkt na Papieskim Wydziale Teologicznym. W 1990 roku objął funkcję redaktora naczelnego „Przewodnika Katolickiego".

Były to czasy, których duchowy rytm w polskim Kościele wyznaczały niezapomniane pielgrzymki Ojca Świętego Jana Pawła II do Ojczyzny. Poprzez nie Kościół powszechny niejako zbliżył się do każdego z nas, a Rzym stał się miejscem znanym i umiłowanym przez Polaków. Dostojny Jubilat czynnie włączył się w ten piękny i potrzebny proces zapoznawania nas z powszechnością Kościoła katolickiego. Na tym odcinku wiele mieliśmy i nadal mamy do zrobienia po długich dziesięcioleciach powojennej wymuszonej izolacji naszego kraju. W 1996 roku nakładem wydawnictwa Pallottinum ukazały się Pejzaże rzymskie - książka wyjątkowa, będąca zarazem prezentacją i namysłem nad Wiecznym Miastem, bez którego - jak stwierdza jej autor - „niepodobna zrozumieć własnego chrześcijaństwa”.

Proszę mi w tym miejscu pozwolić na osobiste wspomnienie ze spotkania z Dostojnym Jubilatem w Rzymie. Było to w roku akademickim 2004/2005, przebywałem wtedy na rocznym urlopie habilitacyjnym, szukając w rzymskich bibliotekach materiałów do rozprawy habilitacyjnej. Mieszkałem w Papieskim Instytucie Polskim i któregoś dnia dowiedziałem się, że ks. biskup Marek przyleciał z Polski i jest okazja do spotkania z tym, który był wówczas moim przełożonym jako kierownik Zakładu Filozofii Chrześcijańskiej. Było nas kilku, z przyjemnością przemierzaliśmy wieczorem uliczki rzymskiego centrum od Piazza Navona do Panteonu. Wydawało mi się, że w miarę dobrze znam ten rejon, przecież dosłownie obok, przy placu Sant'Apollinare znajdowała się moja uczelnia, w której wcześniej spędziłem prawie cztery lata. Podążając za ks. biskupem, znaleźliśmy się na Piazza Sant'Eustachio, gdzie w tamtejszym barze przekonałem się, co to znaczy dobra włoska kawa. Mój promotor, prof. Javier Villanueva, na inne rzeczy zwracał moją uwagę. Zwykł mawiać: „Ucz się i pisz pracę, bo tam $\mathrm{w}$ diecezji le anime ti aspettano - wierni na ciebie czekaja!"”

\footnotetext{
${ }^{4}$ Tamże.

${ }^{5}$ M. Jędraszewski, Pejzaże rzymskie, Poznań 1996, s. 9.
} 
Poprzez papieskie pielgrzymki, w osobie Ojca Świętego Rzym przybliżył się do Poznania, wręcz stanął na placu przy poznańskich Krzyżach, na Łęgach Dębińskich czy w poznańskiej katedrze. Dostojny Jubilat czynnie włączył się w upowszechnianie papieskiej refleksji, jaką mogliśmy usłyszeć właśnie tutaj, w Poznaniu. Służyły temu zwłaszcza kolejne publikacje poświęcone pobytowi i przesłaniu, jakie Ojciec Święty skierował do rodaków w tym mieście: rok 1986 przyniósł książkę: Jan Pawet II w Poznaniu oraz publikację Tekstów poznańskich Karola Wojtyły. Obydwie pozycje ukazały się 11 lat później w kolejnym, poszerzonym wydaniu 6 .

Dnia 20 czerwca 1983 roku podczas drugiej pielgrzymki do Polski papież Jan Paweł II beatyfikował w Poznaniu matkę Urszulę Ledóchowską, bardzo związaną z Pniewami. W 1992 roku Jubilat poświęcił Błogosławionej refleksje zawarte w książce Obrazki z Pniew ${ }^{7}$. Spojrzenie Jubilata w stronę tego niewielkiego wielkopolskiego miasta nie było wtedy dziełem przypadku. We wprowadzeniu, zatytułowanym po prostu Pniewy, stawia sobie i czytelnikowi cały szereg pytań:

Niekiedy jesteśmy uczestnikami wyjątkowych zdarzeń, czasami mamy szczęście spotykać się z Wielkimi. Co w nas z tego pozostaje? Jakie to $\mathrm{w}$ nas wypala piętno? $\mathrm{Z}$ bagażem jakich doświadczeń wyruszamy na spotkanie jutra?

Od jakiegoś czasu są to pytania, które stawiam sobie pod adresem Pniew. Mieszkał w nich, przebywał i pracował Wielki Człowiek. Człowiek Święty. Dzięki niemu Pniewy weszły do historii uniwersalnej. Czy Pniewy są świadome tego faktu? Czy potrafią być z tego dumne? Asyż ma swych Franciszka i Klarę, Ars swego Jana, Lisieux swą Teresę. Maleńkie miejscowości, które dzięki nim stały się słynne na cały świat. Pniewy mają swoją Urszulę. Czy rzeczywiście „swoją"?8

Te pytania, dotyczące spraw prowincjonalnych, prowadzą Dostojnego Jubilata ku refleksji o charakterze uniwersalnym, obejmującej naszą Ojczyznę. Jak wspomina, te myśli i pytania towarzyszyły mu, kiedy 27 października 1991 roku przyjechał po raz kolejny do Pniew. Był to - jak wspomina - dzień pierwszych prawdziwie wolnych wyborów do sejmu i senatu. Tak pisze o panującej wówczas atmosferze w naszym kraju:

U ludzi zmęczenie niełatwą sytuacją, brakiem jasnych perspektyw na przyszłość, głupota, a niekiedy i arogancją tych, którzy wzięli na siebie odpowiedzialność za losy Kraju dochodzi - zda się - do granic wytrzymałości [...] Szum informacyjny, zagubienie, poczucie własnej słabości i błędów zniechęca wielu. Czy warto się jeszcze

${ }^{6}$ Zob. tenże, Jan Pawet II w Poznaniu, Poznań 1986; wyd. 2 poszerzone i uzupełnione, Poznań 1997; K. Wojtyła, Teksty poznańskie, wprowadzenie i wybór, M. Jędraszewski, Poznań 1986; wyd. 2 poszerzone, Poznań 1997.

${ }^{7}$ Zob. M. Jędraszewski, Obrazki z Pniew, Poznań 1992.

${ }^{8}$ Tamże, s. 10. 
raz wysilić? Czy to ciagłe nawoływanie do ofiar i poświęceń nie powinno się wreszcie skończyć? Wszędzie tylko słowa, słowa, słowa...9.

W sierpniu 1920 roku bł. Urszula Ledóchowska przybyła na stałe do Pniew. Wtedy również - jak zaznacza autor - przerażały poselskie spory w Warszawie, podczas gdy od Wschodu narastało straszliwe zagrożenie dla dopiero co odzyskanej niepodległości ${ }^{10}$.

Tę ogromną wrażliwość Dostojnego Jubilata na sprawy związane z naszą Ojczyzną dostrzec można również kilkanaście lat później, podczas obchodów 50. rocznicy Powstania Poznańskiego 1956 roku. Wtedy to Dostojny Jubilat napisał rozważania drogi krzyżowej, która w Wielki Wtorek, 11 kwietnia 2006 roku wyruszyła od bramy Zakładów Hipolita Cegielskiego. Jej tekst ukazał się w tym samym roku nakładem Księgarni św. Wojciecha jako Pasja według Czerwca '56. Współczesny patriotyzm to także ochrona pamięci o tych, którzy oddali swoje życie i zdrowie dla istnienia i pomyślności Ojczyzny. Jednym z nich był ks. arcybiskup metropolita poznański Antoni Baraniak. Aresztowany przez komunistyczny reżim równolegle z ks. prymasem Stefanem Wyszyńskim, osadzony został w Areszcie Śledczym na Mokotowie, gdzie całe lata poddawano go szykanom oraz brutalnym i wyrafinowanym torturom. Temu niezłomnemu bliskiemu współpracownikowi księdza prymasa Dostojny Jubilat poświęcił dwa monumentalne tomy pod wspólnym tytułem Teczki na Baraniaka. W pierwszym z nich, noszącym podtytuł Świadek, przeanalizował na podstawie źródeł aresztowanie i uwięzienie księdza arcybiskupa Antoniego Baraniaka oraz jego 20-letnie rządy $\mathrm{w}$ archidiecezji poznańskiej. Tom drugi, Kalendarium działań $S B$, jest zapisem działań komunistycznego aparatu terroru, wymierzonych w metropolitę poznańskiego. Jak stwierdza we wprowadzeniu Dostojny Jubilat, „Z fragmentarycznie zachowanych dokumentów wyłania się szczególne świadectwo, jakie o arcybiskupie Baraniaku dali - niejako wbrew sobie - funkcjonariusze SB”.

Dnia 17 maja 1997 roku Ojciec Święty Jan Paweł II mianował Dostojnego Jubilata biskupem pomocniczym archidiecezji poznańskiej z tytularną stolicą Forlimpopoli. Święcenia biskupie otrzymał dnia 29 czerwca 1997 roku w katedrze poznańskiej. Rok później otrzymał nominację na stanowisko profesora nadzwyczajnego UAM i kierownika Zakładu Filozofii Chrześcijańskiej na Wydziale Teologicznym UAM, a dnia 2 stycznia 2002 roku otrzymał tytuł naukowy profesora nauk teologicznych. W tym samym roku objął funkcję delegata Konferencji Episkopatu Polski ds. Duszpasterstwa Akademickiego.

Trwająca przeszło 10 lat współpraca naukowa z Dostojnym Jubilatem w ramach Zakładu Filozofii Chrześcijańskiej była prawdziwą przyjemnością, a jako kierownik dał się On poznać jako osoba życzliwa, systematyczna, niezwykle sta-

\footnotetext{
${ }^{9}$ Tamże, s. 10-11.
}

${ }^{10}$ Zob. tamże. 
ranna i wymagająca, przykład autentycznej fascynacji filozofią. Z przyjemnością przyjeżdżaliśmy z obecnym tutaj ks. prałatem Andrzejem Latoniem, wówczas adiunktem na Wydziale Teologicznym, do Poznania na comiesięczne zebrania Zakładu. Początkowo odbywały się one w Zakładzie Filozoficznym w budynku B, a następnie w gościnnych progach domu Dostojnego Jubilata na Ostrowie Tumskim. Czasami koledzy z innych zakładów zazdrościli nam tych częstych i systematycznych spotkań, panującej na nich atmosfery i ... samego kierownika. Warunki mieliśmy rzeczywiście wymarzone i wkrótce w Zakładzie zaczęły się pojawiać rozmaite inicjatywy badawcze, które zaowocowały publikacjami, wśród których wymieniłbym zwłaszcza Transcendencję $i$ odpowiedzialność. W stulecie urodzin Emmanuela Levinasa, która ukazała się w 2006 roku jako trzeci tom zainicjowanego dwa lata wcześniej rocznika „Filozofii Chrześcijańskiej”. Pięć lat wcześniej, jako pierwsi na Wydziale, doprowadziliśmy pod kierunkiem Dostojnego Jubilata do wydania antologii Filozofia. Materiaty do ćwiczeń dla studentów teologii (Poznań 2001), która doczekała się, jak dotychczas, dwóch wydań (myślimy o trzecim) i jest po dziś dzień cenną pomocą w dydaktyce filozofii. Przykłady innych ciekawych inicjatyw można by mnożyć.

Dnia 11 lipca 2012 roku Ojciec Święty Benedykt XVI mianował księdza biskupa arcybiskupem metropolitą łódzkim. Ingres do katedry łódzkiej odbył Dostojny Jubilat dnia 8 września 2012 roku. Jest członkiem Rady Stałej Konferencji Episkopatu Polski i zastępcą jej przewodniczącego. Jest członkiem Kongregacji Edukacji Katolickiej, a także sprawuje funkcję członka Sekcji Nauk Filozoficznych Komisji Nauki Wiary, jest delegatem KEP ds. Duszpasterstwa Akademickiego, członkiem Ogólnopolskiego Komitetu Organizacyjnego Obchodów 1050. Rocznicy Chrztu Polski w 2016 r., członkiem Rady ds. Duszpasterstwa Młodzieży, członkiem Zespołu KEP ds. Wizyty Ojca Świętego w Polsce 2016 r.

Nowy metropolita łódzki dał się poznać na forum Kościoła w Polsce przede wszystkim jako promotor szczególnej inicjatywy, którą są comiesięczne Dialogi w katedrze. W konstytucji duszpasterskiej o Kościele w świecie współczesnym Sobór Watykański II skierował do pasterzy Kościoła następującą zachętę: „Niech dzięki wytrwałym studiom staną się tak przygotowani, aby mogli nawiązywać dialog ze światem i ludźmi wszelkich przekonań" ${ }^{11}$. Tych, którzy znają bliżej Dostojnego Jubilata i mieli zaszczyt z Nim współpracować, nie dziwi ta decyzja, by regularnie spotykać się z wiernymi w katedrze biskupa diecezji. Ośmieliłbym się stwierdzić, że Dialogi w katedrze są swego rodzaju ukoronowaniem intelektualnej drogi Dostojnego Jubilata. Ex abundantia enim cordis os loquitur (Albowiem z obfitości serca mówią usta) - wiemy o tym dobrze i dziękujemy Ci, Księże Arcybiskupie, za ten piękny przykład intelektu wprzęgniętego w biskupią posługę wobec tych, którzy są blisko, i tych, którzy są daleko ${ }^{12}$.

\footnotetext{
${ }^{11} \mathrm{KDK}, 43$.

12 Por. Dz 2,39.
} 